\title{
Hayvanların Acısına Bakmak: Hayvan Foto Muhabirliğine Dair Kavramsal Bir Çerçeve
}

\author{
Savaş Onur ȘEN ${ }^{1}$
}

\section{$\ddot{O} z$}

İnsanların maruz kaldığı vahşetin ve ölü bedenlerin fotoğraflanarak teşhir edilmesi etik açıdan tartışılmakta ancak henüz hayvanlar konusunda böyle bir tartışma bulunmamaktadır. Bir gün, sokak köpekleri ile ilgili gerçekleştirdiğim fotoğraf çalışması için, illegal olarak hayvan kesimi yapılan bir bölgede çekim yapıyordum. Havadaki koku, ayağımın altında kanla ıslanmaktan yumuşamış ve simsiyah olmuş toprak ve çevredeki hayvan parçaları bana James Nachtwey, Don McCullin ve GillesPeres gibi savaş fotoğrafının büyük isimlerini ve onların çalışmalarını düşündürdü. Yakın tarihte dünya yüzeyinde gerçekleşen birçok çatışma ve savaşı fotoğraflayan bu isimler de büyük olasılıkla o an benim duyduğum kokuyu duymuş, toprağın bu renge dönüştüğünü görmüş ve karınlarını doyurmak isteyen diğer hayvanların o çatışma bölgelerinde nasıl dolaştığını görmüşlerdir. "Katliam alanları, birbirinden çok da farklı değildir" diye düşündüğüm o gün insan ya da hayvana uygulanmış olan vahşetin görüntülerinin işlevselliği üzerine düşünmeye başladım. Bu makale, o gün gördüklerim ve hissettiklerim üzerine, fotoğrafın insan acılarını temsil etmedeki rolünü ve bu rolü hayvanlar için oynayıp oynayamayacağını tartışmaktadır. Diğer taraftan, hayvanların acısını görünür kılma konusunda, son yıllarda öncü isimler tarafından ortaya konan, "Hayvan Foto Muhabirliği" kavramının işlevsel olup olamayacağına ilişkin tartışmayı Peter Singer, JudithButler ve Susan Sontag üzerinden gerçekleştirecektir.

Anahtar Sözcü̈kler: Fotoğraf, Hayvan Foto Muhabirliği, Foto Muhabirliği, Hayvan Hakları, Hayvan Haklar1 Fotoğrafçıllọ̆1

\section{Regarding the Pain of Animals: A Conceptual Framework for Animal Photojournalism}

\begin{abstract}
Photographing the brutality and dead bodies exposed by humans is an ethical debate, but there has not been such debate about animals yet. One day, I was shooting in an illegal slaughtering area for my photographic work on stray dogs. The smell in the air, the softened and pitch-black soil because of blood under my feet, and the animal parts in the surrounding made me think of the big names of war photography and their work, such as James Nachtwey, Don McCullin and Gilles Peres. These names, photographing many conflicts and wars taking place on the surface of the world recently, most likely experienced the smell that I felt at that moment, saw how the soil turned into this color and saw how other animals wishing to feed their bellies were wandering around in those conflict zones. That day when I thought, "The massacres are not very different from each other," I started to think about the functionality of the images of the brutality applied to humans or animals. This article, because of what I saw and felt that day, will discuss the role of photography in representing human suffering and whether it can play this role for animals. On the other hand, it will make a discussion about whether the concept of "Animal Photojournalism," which has been put forward by the pioneers in recent years, can be valid on making the pain of animals visible, through Peter Singer, Judith Butler, and Susan Sontag.
\end{abstract}

Key Words: Photography, Animal Photojournalism, Photojournalism, Animal Rights, Animal Rights Photography

\section{Atıf İçin / Please Cite As:}

Şen, S. O. (2021). Hayvanların acısına bakmak: Hayvan foto muhabirliğine dair kavramsal bir çerçeve. Manas Sosyal Arasturmalar Dergisi, 10(1), 696-706.

Geliş Tarihi / Received Date: 26.04.2020

Kabul Tarihi / Accepted Date: 27.09.2020

\footnotetext{
${ }^{1}$ Dr. Öğretim Üyesi - Türkiye- Van Yüzüncü YılÜniversitesi Güzel Sanatlar Fakültesi, savasonursen@gmail.com

(iD ORCID: 0000-0001-6166-0588
} 


\section{Giriş}

Bu çalışma iki temel sorudan yola çıkarak oluşturulmuştur; Birincisi, hayvan foto muhabirliğinin tanımına, ikincisi ise işlevine ilişkin. İlk sorunun yanıtı, bu janrın ne olduğunun ve hangi kapsamda değerlendirilmesi gerektiğinin çerçevesini çizecektir. İkinci sorunun yanıtı ise deney, giyim, yemek ve eğlence vb. amaçlarla kullanılan hayvanların yaşam koşullarının, çektikleri acıların ve uğradıkları korkunç işkencelerin görünür kılınmasında ve bu koşulların değiştirilmesinde hayvan foto muhabirliğinin işlevsel olup olamayacağının yanıtını arar. Bu yanıt, yalnızca hayvanlarla fotoğraf vasıtasıyla kurulan ilisskide ortaya çıkmaz; fotoğrafin, özellikle de vahşeti yansıtan fotoğrafların işleviyle ilgili tartışmaları da beraberinde değerlendirme gerekliliğini ortaya koyar.

Kısaca insanların işgal ettiği dünyada sıkışıp kalan hayvanlarla kurulan yıkıcı ilişkinin ifade ve/veya temsil edilme biçimlerinin, hayvan refahının tesisi ya da hayvanların yaşam koşullarının iyileștirilmesi konusunda faydalı olup olmayacağına dair tartışma bu makalenin konusunu oluşturur. Makalede hayvaninsan ilişkisi, Peter Singer'ın yaklaşımı dâhilinde ortaya konacaktır. Singer bu ilişkiyi pratik etik çerçevesinde ele almaktadır. İlk basısını 1975 yllında yapan, "Hayvan Özgürleşmesi”" kitabı ile hayvan hakları konusunda öncülerden biri olan Singer'n faydacı yaklaşımına göre, canlıların çıkarlarının eşit derecede önemsenmesi gerekmektedir. Bir canlının çıkarını belirleyense onun acı çekme ya da haz duyma kapasitesidir. Hayvanlar evrimsel süreçte edindikleri merkezi sinir sistemine bağlı olarak acıyı ve hazzı hissedebilirler. Acıy1 ve hazzı hissetme kapasitesi hayvanların çıar sahibi birer canlı olarak değerlendirilmelerini gerektirir. Eşitlik ilkesi gereği her canlının çıkarları eşit bir biçimde önemsenmelidir. İnsanların dünyasında acı çeken hayvanların acılarının fotoğrafik temsilini üstlenen hayvan foto muhabirliğinin temel güdüsü de acıların eşit önemsenmesini sağlamaktır. Bu noktada, fotoğrafin ve/veya hayvanların acılarının fotoğraf aracıllğıyla yeniden sunumu, kitleler üzerinde yaratacağı etki Judith Butler ve Susan Sontag'ın görüşleri çerçevesinde değerlendirilecektir. Bu tartışmada eşitlik ilkesine aykırı olan 1 rkçlık ve cinsiyetçiliğin yanına konuşlandırılacak olan türcülüğün yarattığı öteki olarak hayvan hayatının, yası tutulabilir ya da kırılgan olarak kabul edilmesine iliş̧kin görüşleri nedeniyle öncelikle Butler ele alınacaktır. Zira Butler'a göre belirli çerçeveler etrafında belirlenen kriterler öncelikle bir hayatın hayat olarak ön kabulünü gerektirmektedir. Ardından Sontag'ın başta bu makalenin adına ilham veren, "Başkalarının Acısına Bakmak" adlı kitabında ortaya koyduğu görüşler çerçevesinde, fotoğrafların insan acılarını yansıtmak konusundaki işlevlerine ilişkin görüşlerine yer verilecektir. Son olarak, bu kapsamda, "Hayvan Foto-muhabirliğ̣”" ya da "Hayvan Hakları Fotoğrafçllığı" ve bu janrın işlevselliği tartışlacaktır.

Homo Sapiens'in diğer türlerle kurmuş olduğu ilişki farklı biçimlerde ortaya çıkmış, insan ve diğer hayvanlar arasındaki ilişkiler ağı çağlar boyunca diğer türler için yıkıcı olmuştur. Bu yıkıcı ilişkinin yaşandığ1 tarihsel süreç içerisinde birçok tür yeryüzünden silinmiş, birçoğu da evcilleştirilmiştir. Günümüzde insan varllğının gezegen üzerinde giderek yayılması sonucu yabani hayvanların yaşam alanları hızla istila edilmekte, diğer taraftan endüstriyel üretimle birlikte hayvanlar, uygunsuz koşullarda büyütülmekte, doğar doğmaz anne ya da yavrularından ayrilmak zorunda bırakılmakta ve kısacık ancak acı dolu yaşam sürelerinin ardından ölüme gönderilmektedir. Son yllarda, bu süreçlerin belgelenerek kamuoyuna ulaştırılması ve bu konuya dair duyarlılığın arttırllarak hayvanların sesinin duyurulmasını sağlamak amaciyla başta fotoğraf olmak üzere farklı görsel anlatım yöntemleri kullanılmaya başlanmıştır. "Hayvan Foto Muhabirliğ̣”" ya da "Hayvan Hakları Fotoğrafçıllğı" olarak adlandırılan bu yaklaşım; insanların dünyasında farklı gerekçelerle işkence gören hayvanların yaşadıklarına tanıklık etmek ve onların acılarını kamuoyuna sunmayı amaçlamaktadır. Hayvan Foto Muhabirliği, adından da anlaşılacağı üzere, foto muhabirliği anlatısına uygun bir şekilde konusunu insan dışındaki hayvanların yaşam koşullarından almaktadır. Özellikle günümüzde oldukça popüler bir hal alan vegan hareket tarafindan kullanılan imajlar, hayvan hakları ve hayvan refahı konularında kamuoyunda bir karşılık bulma amacı taşımaktadır. Hayvan foto muhabirliğinin ayrıntılarına girmeden önce Peter Singer'ın görüşleri dahilinde insan ve hayvan arasındaki ilişkiyi ele alalım.

\section{Acının Eşitliği}

Hayvan refahı konusunu bir etik problem olarak ele alan Peter Singer alanın öncülerinden biridir. Peter Singer hayvan hakları ve hayvan refahı konularında savunduğu eşitlik düşüncesi ve ardından ortaya koyduğu kuramla, başta endüstriyel tarımda, tıp ve kozmetik alanlarında deney hayvanı olarak kullanılan hayvanlar olmak üzere, deniz canlılarından evcil hayvanlara kadar birçok alanda insanların dünyasında 
sıkışıp kalmış hayvanlara ilişkin önemli düşünceler ortaya koymuştur. Singer ayrıca ilk olarak Richard Ryder’’n kullandığı, “Türcülül”” kavramı ile günümüzde insanın kendi dışındaki türlerle kurduğu ilişkiyi kategorize ederek türcülüğü, ırkçılık ve cinsiyetçiliğin yanı başında konumlandırmıştır.

1975 yılında yayınlamış olduğu "Hayvan Özgürleşmesi" adlı kitapla dünya genelinde hayvan refahı konusunda önemli bir etki yaratan Singer'agöre öz benliğinin farkında olma, zeka ya da dil gibi özellikler hayvanlarla kurduğumuz ilişkiyi anlamlandırmak için doğru noktalar değildir(2018, s.50). Singer insan dışındaki hayvanların dünyadaki varlığını haz ve acı çekme kapasiteleri üzerinden yorumlamamız gerektiğini savunmaktadır. Singer ortaya koyduğu etik yaklaşımla, çıkar sahibi tüm canlıların eşit derecede önemsenmeleri gerektiğini savunur, bunun ön koşulu ise haz duyma ve acı çekme yetilerine sahip olmaktır. Acıdan uzak yaşamak her canlının çıkarınadır ve bu anlayışa göre merkezi sinir sistemine sahip olan her canlı eşittir. Singer bir canlının insan olarak dünyaya gelmiş olmasından dolayı diğer türlerden üstün ve değerli olduğunu iddia etmenin temel eşitlik ilkesine aykırı olduğunu savunmaktadır. Doğru eylem, diğer canlıların bizim eylemlerimizden ne denli etkileneceklerini düşünerek yapılan ve etkilenecek olanların tümünün eşit derecede etkileneceğini gözeterek gerçekleştirdiğimiz eylemdir.

Singer eşitlik ve hayvanların çıkar sahibi birer canlı olduğuna ilişkin görüşlerini ahlak felsefesinde faydacı okulun kurucusu Jeremy Bentham'ın düşüncesi üzerine kurgulamıştır. Jeremy Bentham'ın faydacı felsefesini sürdüren Singer, farklı varlıkların çıkarlarının da eşit derecede önemsenmesi gerektiğini savunmuştur. Bentham ve onu takip eden Singer'a göre acı çekme kapasitesi çıara sahip olmanın ön koşuludur. Bir varlık acı çekiyorsa, bu acıyı önemsememek için hiçbir ahlaksal gerekçe öne sürülemez (Singer, 2018, s. 55). Bentham'a göre herkes bir saylmalı ve belli bir eylemden etkilenen bütün varlikların çıkarları göz önünde bulundurulmalı ve bütün varlıkların çıkarları eşit derecede önemli sayılmalıdır. Bentham her varllğın eşit derecede önemsenme hakkına sahip olduğu görüşünü, o varlığın acı çekme kapasitesiyle ilişkilendirmektedir. Ona göre, hayvanlarla ilgili sormamız gereken soru, "Akıl yürütebiliyorlar mı?” ya da "Konuşabiliyorlar mı?” değil, "Ac1 çekebiliyorlar mı?” olmalıdır (Aktaran, Singer, 2018, s. 54).

Eşitliği temel bir etik ilkesi olarak kabul eden Singer'a göre, çıkarların eşit gözetilmesi ilkesinin özü, bir eylemden etkilenenlerin benzeri çıkarlarına eşit derecede önem vermekten geçer yani, önemli olan kimin çıkarının olup olmadığı değil ortada bir çıkar olduğudur (Singer, 2015, s. 46). Bu çerçevede Singer'ın, farklı varlıkların eşit derecede önemsenmesini gerektiren temel eşitlik ilkesi üzerine kurduğu acı çekme yetisinden doğan çıarlar, cinsiyet, ırk ya da tür gibi kavramlarla ihlal edilemez. Şayet bir kişinin kendi biyolojik türünün çıkarları lehine ve diğer türlerin aleyhine önyargılı bir davranış ya da tutum ortaya konuyorsa orada "Türcülük" söz konusudur. İlk olarak Richard Ryder tarafindan kullanılmış olan, "Türcülük" kavramını geliştiren Singer, türcülüğün eşitlik ilkesi çerçevesinde, tıpkı ırkçlık ya da cinsiyet ayrımcllı̆̆ gibi reddedilmesi gerektiğini savunur (Singer, 2018, s. 53).

Singer, hayvanlara karşı uygulanan sömürünün kökeninde, iki bin yıldır Batı düşüncesinde hayvanlara karşı geliştirilmiş olan yaklaşımın bulunduğunu ve bu ideolojiyi deşifre ederek ortaya koymanın, onu aşarak köklü değişimler sağlamanın temeli olduğunu vurgulamaktadır. Bunun dışında gerçekleşecek iyileştirmeler, her an geriye dönebilme potansiyeli taşımaktadırlar (Singer, 2018, s. 322). Singer özellikle günümüzde hayvanların medyadaki temsillerini, kökenini iki bin yıl öncesine kadar dayandırdığı ideolojinin devamını sağlayan bir unsur olarak görmektedir:

\begin{abstract}
Amerikan televizyyonlar neredeyse her akşam yabani ortamlarda yaşayan hayvanlar gösteriyor (gerçi bunlar her zaman yabani olmuyor; bazen bayvanlar çekim yapmayn kolaylastirmak için yakalanyyor ve etrafi cevrili bir alana konuyorlar); ama yoğun hayvanchllk yöntemlerini ancak nadiren yaymlanan tarm ve gida üretimine

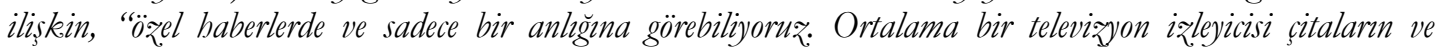
köpekbahklarmm hayatm tavuklarm ve süt buzağzlarmm bayatmdan çok daba iyi biliyor olmal. Sonucta televisyonda giftlik. hayvanlarna iliskin en çok. "Bilgi" reklamlardan alnabiliyor. Bu reklamlardan bazllarnda sosis olmak isteyen domuzlar veya konserve olmaya çalısan ton ballklarm gösteren sasma sapan çizgi filmlere,

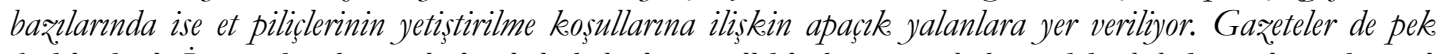
farkh değil. Insan diş hayvanlarla ilgili haberler genellikle hayvanat bahçesindeki bebek goril ya da nesli teblikede olan türler gibi "insanlarn ilgisini çekecek" konulara iliskin oluyor; hayvanculhe. tekniklerinde milyonlarca hayvanm hareket serbestisini engelleyecek gelismeler ise es geçiliyor (Singer, 2018, s. 325).
\end{abstract}

Bugün milyarlarca hayvan dakikalar içinde katledilmekte, birçok tür hızla yeryüzünden silinmekte ve bu ölüler birer hayalet olarak sayıyla bile değil ağırlık birimleriyle ölçülmekte, yaşamlarına ve ölümlerine ilişkin idraki ortaya çıkaracak bir ideoloji ya da toplumsal bilinç düzeyi bulunmamaktadır. Bu hiyerarşinin 
üst basamaklarında bulunan ırk ve cinsiyetle ilgili koşullar toplumsal olarak inşa edilebilir. Bu inşa sürecinde hayvanların acısını hiyerarşik olarak nerede konumlandırmamız ve onların yaşamlarının yaşanmış olarak kabul edilip edilmeyeceği ve bu statü ya da kategori belirlenirken yaşanabilirliği kabul edilen hayatın yanı sıra imha edilmesi gereken hayat da belirlenecektir. Bu noktada hangi hayatın yaşanabilir ve yası tutulabilir olduğunu bazı normlar ve çerçevelerin belirlediğini savunan Judith Butler'in görüşleri çalışma açısından anlam kazanmaktadır.

\section{Ötekinin Acıs1}

Eşitlik ilkesi tüm varlıkların çıkarlarının eşit derecede önemsenmesine dayanır. Bunu belirleyen ise "hissetme" kapasitesidir. Varlı̆ı̆n çıkarına aykırı bir muamele ile karșılaşmış olmasıııın nedeni, ister ırkı ya da cinsiyeti isterse de biyolojik türü olsun bu durum ayrım gözetmeden çıarlarının eșit derecede önemsenmesini gerektirir. Böylelikle şunu söyleyebiliriz, bir canlının biyolojik olarak mensup olduğu tür, ırk ya da toplumsal cinsiyeti, bunların yanı sıra ahlaki statüsü ya da zekâ kapasitesine ilişkin sınıflandırmalar eşitlik ilkesi açısından kıymetsizdirler. Bu anlamda, hangi hayatların yaşanmış ya da yaşanan hayatlar olarak kabul edilip edilmediğine iliş̧in Judith Butler'ın yaklaşımının bu çalışma için hayati bir noktada olduğu açıktır. Ona göre, belirli hayatların incinmiş ya da kaybedilmiş hayatlar olarak kavranabilmesi için öncelikle yaşanmış hayatlar olarak kavranmaları gerekmektedir (Butler, 2015, s. 9).

Judith Butler hayattan sayılmayan ya da başından itibaren belirli epistemolojik çerçeveler dahilinde kavranabilir olmayan hayatların tam anlamıyla yaşanmış ya da kaybedilmemiş sayılmayacağını belirtmektedir (2015, s. 10). Bedenin varlı̆ğın belirleyen siyasal ve toplumsal örgütlenmelerdir. Bu anlamda bedenin ontolojisi, toplumsal biçimlere maruz kaldıkça ve toplum tarafindan işlendikçe toplumsal bir ontoloji halini alır. Butler'a göre bedenin ontolojisini belirleyen çerçeve siyaseten belirlenir ve idrak edilen ve idrak edilemeyen hayatlar arasında ayrım yapmamızın koşullarını belirleyen iktidardır.

Butler varllğını iddia ettiği yas hiyerarşisini belirleyen temel etkenler olarak 1rkçllık ve cinsiyetçiliğin altını çizmiş ancak bu hiyerarşi kapsamında hayvanlardan bahsetmemiştir. Bu noktada eşitlik ilkesini ve hissetme kapasitesini dikkate alacak olursak Singer'ın eşitlik ilkesine aykırı bulduğu ve rrkçllık ve cinsiyetçiliğin yanında konuşlandırdığı türcülük kavramını, yaşanabilir hayatı ve yaşam ya da ölüm hiyerarşisindeki konumu belirleyen kavramlardan bir diğeri olarak kabul edebiliriz. Böylelikle insan dış1 hayvanların, bu hiyerarşideki en sonlarda yerlerini aldıklarını söyleyebiliriz. Güçlü de (2018) Butler'ın tartışmayı insan merkezli olarak yürütmesini, "hayvanı reddettiğı" için değil de görüşlerini, odaklandığı tarihsel olay nezdinde ortaya koyduğu için retorik açıdan insan merkezli olarak sürdürdügünün öne sürülebilir olduğunu savunmaktadır. Ona göre, Butler’nn, "yaşamdan sayllan yaşam"1 sadece insan-olanla eşitlediği ya da hayvanın yaşamını yaşamdan saymadığı sonucuna varmak güçtür. Butler'ın kendisi de bir röportajında, eğer ki kırılganlık insanın sadece diğer insanlarla paylaştığı bir şey değil de hayvanlarla ya da çevreyle de paylaştığı bir durumsa, o zaman "kırılgan hayat"1 insan-merkezli olmayan bir çerçevede, bir yaşamı değerli kılanın ne olduğu üzerinden düşünmeyi önerir (Akt: Güçlü, 2018). Ayrıca Butler, "İsskence ve Fotoğraf Etiği: Susan Sontag'la Birlikte Düşünmek” adlı, birçok noktada fotoğrafların ve özellikle savaş fotoğraflarının işlevine ilişkin Susan Sontag'a itirazlarını sunduğu makalesinde, yaşanabilir hayatın normlarının, bunların temsilini ve anlamlandırılmasını sağlayan çerçevelerin dışında belirleyici olanın acı olduğunu iddia eder. Bu acıyı insana özgü ya da insanda örneklenen acı olarak ele almak yanlış olur. Ona göre, insan tam da insan hayvanı olarak acı çeker (Butler,2015, s. 76). Butler'ın acı çekme potansiyeli söz konusu olduğunda konuyu insan özelinde ele almadığını görüyoruz.

Butler, ötekinin hayatının gerçekliği üzerine gerçekleştirdiği tartışmayı yası tutulabilir olan ve olmayan üzerinden ortaya çıkan "yas hiyerarşisi” ile başlatır (2018, s. 46). Buna göre, belirleyici olan, kimin insan ve kimin yaşamının yaşam sayıldığı ön kabulüdür. Dünya yüzeyindeki kimi yaşamlar, mutlak korunması gereken ve kutsiyet atfedilen yaşamlarken, bazı yaşamlar ise yaşamdan sayılmayacak, hatta yası tutulabilir olarak bile algılanmayacaktır. İnsan olanın ya da insan yaşamı olarak kabul edilenin, içinde var olduğu toplumsal çerçeve ve kültürel sınırlar aynı zamanda çerçevenin dışında kalanı da tanımlar. Çerçevenin içinde yer alan yas hiyerarşisinin en üstünde konumlandırılırken, dışarıda kalan, yası tutulmayacak olana tekabül eder. Bazı ölülerin, adı, ailesi, geleceğe dair hayalleri, yüzleri ve bakışları varken ötekilerin yaşamlarının gerçekliği bile ellerinden alınmıştır. Butler(2018, s. 48), "Gerçek olan nedir?" ve "Kimlerin yaşamları gerçektir?" diye sorar. Ardından gerçeğin dışına itilen, insanlıktan çıkarılan ve yadsınan yaşamların şiddetle ilişkisini şu sorularla irdeler, "Şiddet bu gerçekdışllı̆ı etkiler mi??, "Şiddetin meydana gelmesinin koşulu bu gerçekdışılık mıdır?" Yadsınmış yaşamlar, tuhaf bir şekilde canlı kalırlar ve tekrar 
tekrar yadsınmalıdır ancak bu kayıp yaşamların yasları tutulmaz, çünkü zaten kayıptırlar daha doğrusu hiç olmamışlardır ve öldürülmelidirler. Bu yaşamlar ölülük halinde bile inatla varlıklarını sürdürüyor gibidirler ve bu görüntüdeki tüketilmezlik karşısında şiddet kendisini yeniler. Öteki’nin gerçeklikten çıkarılmasının anlamı onun ne canlı ne de ölü olduğu, tükenmeksizin hayaletsi olduğudur.

Fotoğraflanan ya da fotoğraflanmaya değer görülen hayat yas hiyerarşisi içerisinde daha yukarılarda yer alacaktır. Butler, her ne kadar, özünde işkenceci ya da özgürleştirici olmadığını ancak söylem düzeyinde çerçeveleme şekline ve ne tür bir medya aracıllğıyla sunulduğuna göre değişiklik gösteren ve birbirinden tamamen farklı amaçlarla araçsallaştırılsalar da (Butler, 2015, s. 90) fotoğrafların bir hayatın yası tutulabilir bir hayat olduğunun teyidi olduğunu yani fotoğraflanan bir hayatın aynı zamanda yası tutulabilen bir hayat olduğunu ifade eder. Butler'a göre fotoğraflar huzurumuzu kaçırıyorsa bir kayıp yaşanmış olduğunun dolayısıyla bir hayatın yaşandığının kanıtıdır:

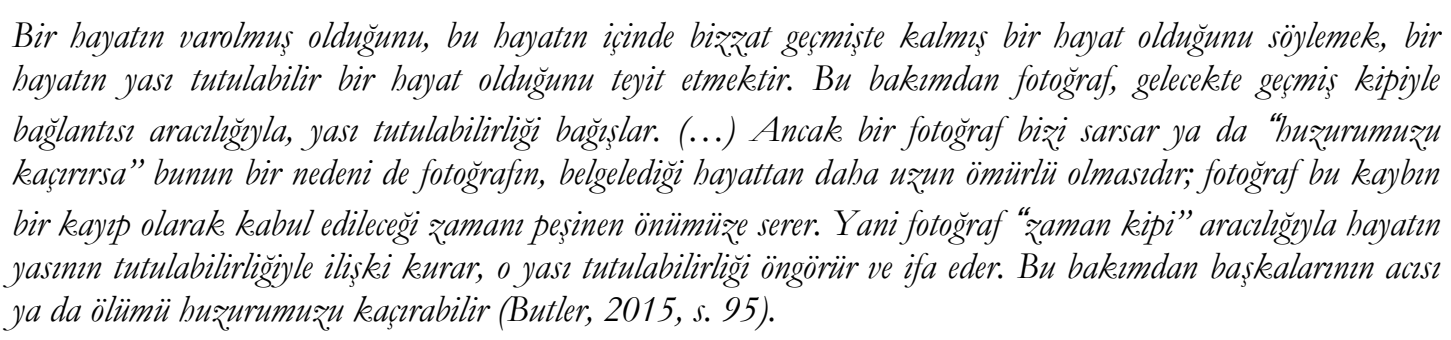

Fotoğrafın, insanların acılarını yansıtmak ya da sorunlarına çözüm bulmak açısından işlevi tartışmalı bir alan olarak karşımıza çıkmaktadır. Butler, bu işlevi bir adım gerisinden ele alarak fotoğrafların öncelikle bir hayatın yaşanmış olduğunu teyit ederek o yaşamlara yası tutulabilirlik bağışladığını belirtmektedir. Bu bağış, hayvan yaşamı ve refahı konusunda çok önemli bir aşamanın da göstergesi haline gelebilir. Hayvan foto muhabirliği, hayvanların yaşam koşullarını ve yaşadıkları sıkıntıları anlatmak ve hayvanları görünür kılmak iddiasındaki fotoğrafikbir yaklaşım olarak bu noktada hayvan yaşamının hem fotoğraflanabilir düzeyde kıymetli hale gelmesi hem de yası tutulabilirlik bağışlanarak yas hiyerarşisinde daha yükseklere tırmanması açısından önem taşımaktadır. Hayvan foto muhabirliğini Susan Sontag'ın fotoğrafa dair görüşleri çerçevesinde ele alarak işlevselliğini bir sonraki başlıkta tartışmak istiyorum.

\section{Acının Bağlamı}

Susan Sontag özellikle fotoğrafin hikâye anlatabilme gücü ve kanıt olma niteliğine ilişkin görüşleri nedeniyle hayli tartışılmaktadır. Fotoğraf yazınında önemli bir yer kaplayan Sontag'in düşünceleri arasında makalenin sınırlılıkları açısından ele alacağımız temel iki nokta söz konusudur. Birincisi Sontag'ın, "Başkalarının Acısına Bakmak" kitabında ele aldığı ve şiddete maruz kalmış olan hangi bedenlerin fotoğrafinın çekilmeye değer, hangilerinin ise sergilenemeyecek kadar sayg1 değer olduğuna ilişkin görüşleri, ikincisi ise Sontag'ın fotoğrafların hikâye anlatabilme kapasitesine dair görüşleri ve buna bağlı olarak ortaya çıkan, "bağlam" sorunsalıdır. Sontag(1999, s. 32), fotoğrafin ölümle olan ilişkisini vurgulamakta ve bütün fotoğrafların "mementomori" olduğunu iddia ederken, fotoğraf çekmenin, bir başka kişinin ya da şeyin ölümlülüğüne, incinebilirliğine ve değişebilirliğine katıllmak demek olduğunu öne sürmektedir. Böylelikle Sontag'n fotoğraf ve onun nesnesiyle kurduğu ilişkide temel dayanağın ölüm ve incinebilirlik olduğunu söyleyebiliriz.

Yukarıda sıraladığımız ve Sontag'ın görüşleri çerçevesinde ele alacağımız iki önemli nokta, hayvan foto muhabirliğine ilişkin bu kavramsallaştırma çabasının gerekliliğini ortaya koyacaktır. Hayvan foto muhabirliği, hayvanların acısına bakmanın bir bağlam etrafinda söylem haline gelmiş ve hayvanların yaşadığı vahşeti bu şekilde görünür kıılma amacını taşıyan bir fotoğraf yaklaşımıdır. Hayvanları konu alan az sayıda fotoğraf çalışmasında hayvan hayatının, yaşanan bir hayat olarak değil, insan yaşamına hizmet eden ve birer nesneye dönüştürülmüş yardımcı etken olarak sunulduğu gözlemlenmektedir. $\mathrm{Bu}$ sebeple, Sontag'in acının ve vahşetin yansıtılmasına iliş̧kin görüşlerini en başta türlerin ya da 1rkların hiyerarşisi bağlamında ele alacağım. Adı geçen kitapta Sontag tartışmanın bizim açımızdan en çarpıcı kısmını şu şekilde ortaya koymaktadır:

Genel olarak bakuldiğında, yayın organlarnnda çıan fotoğraflarda gösterilen feci biçimde sakatlamp yaralanmıs bedenler Asyahlara ya da Afrikahlara aittir. Bu gazetecilik adeti, egzotik (yani, sömürgelestirilmiss) insanlarn cekinmeden teşbir etmeyi matah belleyen ve kökü̈ yüzynllara dayalı bir pratigin mirasıdrr: nitekim, Afrikahlar

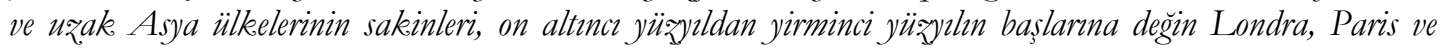
diğer Avrupa başkentlerinde açlan etnolojik sergilerde bayvanat bahçesi bayvanlar gibi teşhir edilmişlerdir (...) 
Egzotik ülkelerde yaşayan koyu renkli insanlarn başlarna gelen canavarlkklarn fotoğraflarmm sergilenmesi,

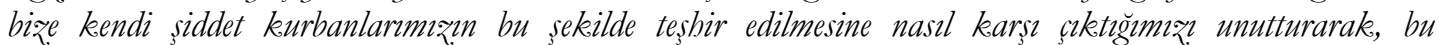
allskeanluğ devam ettirmektedir; ne de olsa ötekiler, düsman saylmadıklarnda bile, aym zamanda (bizim gibi) bakan kişiler değil, yalnızca (kendilerine) bakılacak kişiler saynlmaktadirlar (Sontag, 2004, s. 73).

Sontag’a göre günümüzde de ötekinin ve egzotik olanın sergileme değerine sahip birer nesne olarak sunulmasının kökenleri geçmişte ve hayvanat bahçelerinde bulunmaktadır. Bu durum vahşet kurbanlarının bedenlerinin teşhirinde de bir hiyerarşinin varlı̆̆ını ortaya koymaktadır. Zira Sontag'a göre ölü Amerikan askeri söz konusu olduğunda, çıplak yüzün gösterilmesine karşı her zaman güçlü bir yasaklama eğilimi gözlenmekte ancak savaşın geçtiği yer ne kadar uzak ya da egzotik olursa, ölüleri ve ölmekte olan kişileri tam cepheden gösteren resimlere sahip olma ihtimalimiz de o ölçüde artmaktadır (Sontag, 2004, s. 70-71). Bu tasnife göre vahşet fotoğraflarında iki ayrı statü ortaya çıkmaktadır. Birincisi, fotoğrafı çekilmeye değer olmak, ikincisi ise gösterilmesi sakıncalı bulunacak kadar değerli olmak. Neyin bakmaya değer ve neyi gözlemlemeye hakkımız olduğu konusundaki görüşlerimizi belirleyen fotoğraflar (Sontag, 1999, s. 19), böylelikle nesnesine göre vahşetin seyirlik olup olamayacağını da belirlemiş olurlar.

Sontag'ın sözlerinden anlaşılacağı üzere, hayvanat bahçelerinin varllğı üzerine bir sorgulama ya da hayvanların sergilenme değeri üzerine bir tartışma henüz yeryüzünde bulunmamaktadır. Vahşet fotoğraflarının nesnelerinin sergilenebilir olmalarının kökeni hayvanlar gibi sergilenmelerine dayandırılmakta ve bu duruma karşı eleştirel bir bakış ortaya konmaktadır. Yani burada sorgulanmakta olan, fotoğrafı çekilecek kadar değerli görülenin, neden sergilenmeyecek kadar değerli ya da saygın kabul edilmediğidir. Sontag bu durumu, öteki, uzak ve egzotik kavramlarıyla açıklar(Sontag, 2004, s. 73).

Fotoğrafin, bu bağlamda, tartışlan işlevselliği insan acıları ve onların temsiline ilişkin olarak karşımıza çıkar. Bu aşamada, fotoğraf tarihine dönüp baktı̆̆ımızda, konunun insan hayatı ve insan bedeni üzerinden biçimlendiğini ve fotoğrafların oluşturulma, kamuoyuna sunulma ve insanları etkileme potansiyellerinin antroposentrik bir bakış açısıyla ortaya konduğunu söylemeliyiz. Vahşet fotoğraflarına dair yukarıda ortaya konan iki kriter, hayvanların uğradığı vahşete ilişkin fotoğrafların tarihte kapladığı yeri tanımlamaktan çok uzaktır. Daha doğrusu fotoğraflara atfedilen, tanık olma, sorunları yansıtma ve kamuoyuna duyurma gibi nitelikler hayvanların acılarıla birlikte anılmamaktadır bile. Zira hayvanların uğradığı kıyıma, insan yaşamının kiyısında köşesinde kendilerine yer bulmaya ve yaşamlarını sürdürmeye çalışırken maruz kaldıkları zulme ilişkin yapılmış fotoğraf çalışmalarına rastlamak tarihin ancak yaşadığımız şu son dönemine nasip olmuş, öncesinde hayvanlar kendilerine fotoğraflarda çok az yer bulmuştur. Bu mevcudiyet içinde ise hayvan, insan yaşamına dair yardımcı bir unsur olarak "araç", doğaya karşı koymanın ve ona hükmetmenin bir sembolü olarak "vahşi", uzak coğrafyalara olan merakı tatmin eden bir keşif nesnesi olarak "egzotik", merhametin göstergesi olarak "evcil hayvan", bir takım endüstrilerin hem hammaddesi, hem manipülasyon arac1 olarak "meta"... biçimlerinde temsil edilmiş, nesneleştirilmiş ve insan güdü ve ihtiyaçlarının giderilmesinin araçsal bir ötekisi olarak sunulmuştur. Bu öteki ise bir araç ve otomat olarak kabul edilmiş bir öteki olduğu için hiyerarşik olarak insan ötekiden çok daha aşağıda ve buna bağlı olarak acı çekip çekmediği bile tartışlan ve acısı görülmeye ve fotoğraflanmaya değer bulunmayan bir ötekidir.

Tam da bu ötekiyi temsil edebilmek adına ihtiyaç duyduğumuz şey, onu kavramsal çerçeve içerisinde tanımlayan ve belli bir bağlam içerisinde sunan bir fotoğrafik yaklaşım yani, hayvan foto muhabirliğidir. Bu noktada bir kez daha Sontag'a dönerek onun ortaya koyduğu en tartışmalı zeminlerden biri olan fotoğrafin etki ve gücüne ilişkin görüşlerini ele almamız gerekmektedir. Sontag belgesel fotoğraf ve fotoğrafların kanıt olma niteliğine mesafeli yaklaşmakta ve bu konuya ilişkin görüşleri birçok açıdan tartışmalı alanlar yaratmaktadır. O fotoğrafın anlatım gücüne ve bir anlamı aktarması fikrine karşı oldukça mesafeli durmaktadır. Tutkuyu tetiklemeye yarayan fotoğraflardan, insani ve vicdani yaklaşımlara, safari fotoğraflarından savaş fotoğraflarına kadar fotoğrafin yaptığı şey, dünyayı birbiriyle ilişkisiz, bağımsız parçacıklardan oluşan bir dizi haline getirmek; geçmiş ve bugünüyle tarihi ise bir anekdot, kısa haberler dizisine dönüştürmektir. Sontag'a göre dünya, fotoğraflar yoluyla atomik, başa çıkılabilir ve opak hale gelir. $\mathrm{O}$, bir fotoğraftan kimsenin bir şey anlayamayacağını ve kendi başlarına hiçbir şeyi açıklayamayan fotoğrafların çıkarıma, spekülasyona ve fanteziye bitmez tükenmez birer çağrı olduğunu savunur (Sontag, 1999, s. 39). Fotoğrafların çoğu zaman bir kanıt olarak kabulünü anlamlı bulmakla birlikte fotoğrafları hikaye anlatmadıkları ve anlamı bir bütün olarak sunmadıkları için güvenilmez bulmaktadır. Sontag modern dünyanın insanları birer görüntü bağımlısına dönüştürdüğünü, bunu sağlayanın ise fotoğraflar 
yoluyla gerçekliği onaylama ve deneyimi arttırma gereksinmesi ve bugün herkesin bağımlısı olduğunu iddia ettiği estetik bir tüketicilik olduğunu savunur (Sontag, 1999, s. 40).

Ancak Sontag fotoğrafa ilişkin bu olumsuz yargılarının istisnalarını satır aralarında ortaya koymaktadır. Ona göre, bazı görüntüler vicdanı harekete geçirebilir ve bunlar kamuoyunda bir iz bırakabilir ancak bu her zaman belirli bir tarihi durumla ilgilidir. Bu tip fotoğraflar ne kadar genelse onların etkisi o denli azalacaktır ancak fotoğrafa kamuoyunu etkileme gücünü veren onun bağlamıdır (Sontag, 1999, s. 33).

\section{Bugün bir olay kesinlikle fotoğraflanmaya değer bir şey anlamma gelse de, bala o olaym nelerden olusttuğunu belirleyen tek, sey (en genis anlamiyla) ideolojidir. Bir olaym kendisi isimlendirilip tanmmlanmcaya kadar, o olaya ait fotografik ya da baska tür bir kannt bulunamaz. Ve olaylar olusturabilen -daba doğrusu tanmlayan- sey biçbir zaman fotografik kannt değildir; fotoğrafin katkess her zaman olayin isimlendirilmesinden sonra gelir. Fotoğraflarn ablaki olarak etkili olup olamayacă̆g, ilgili bir siyasi görïsï̈n var oluşuna bağhder. Ardinda bir siyaset olmadan, taribin kiym fotoğraflarnna herbalde yalmaz̧a gerçek diş ya da moral bozucu duygusallıklar olarak. bakilacaktur (Sontag, 1999, s. 35).}

Hayvan ötekinin temsil edilmesine ve onun yaşadığı 1stırapların ortaya konmasına dair zorunluluk özellikle modernite sonrası sürecin bir getirisi olarak insan ve hayvanların ilişkilerinde yaşanan kopuşun sonucudur. John Berger bu süreci şu şekilde ele almaktadır; Batı Avrupa ve Kuzey Amerika'da 19. yy.da başlayan ve insanla doğa arasındaki her türlü uzlaşma geleneğinin sona erdirilme süreci ile beraber insanların, üretim araçlarındaki ve toplumun herhangi bir örgütlenmesindeki herhangi bir değişimde, yiyecek, iş, ulaşım ve giyecekleri için hayvanlara duydukları ihtiyaç ortadan kalkmıştır. Böylelikle daha öncesinde hayvanlar insanlarla birlikte insan dünyasının merkezindeyken 20. yüzyll kapitalizmiyle birlikte bu süreç tamamlanmıştır (Berger, 2017, s. 18). Hayvan foto muhabirliğini, düşünsel ve pratik boyutta ortaya çıkaran zorunluluğun temelleri bu açıdan hayvan ve insan ilişkisinde yaşanan bu kopuşa dayanmaktadır. Günümüzde, ekolojik tartışmalar, küresel ısınma ve hayvan hakları aktivistlerinin oluşturduğu düşünsel altyapı hayvanların acısına bakma zorunluluğu çerçevesinde hayvan foto muhabirliğinin varlık nedenlerini oluşturmuştur.

\section{Acının Temsili}

Hayvan foto muhabirliğini; hayvan hakları ihlallerinin fotojurnalistik üslupla gözler önüne serildiği, hayvan refahına ilişkin konuların ele alınarak kamuoyunda temsil edilme şansı olmayan hayvanların görsel olarak temsil edilmesini amaçlayan bir anlatım dili olarak tanımlayabiliriz. Hayvan foto muhabirliği bu anlatıyı gerçekleştirirken, birer gösteri nesnesine dönüştürülmüş ya da farklı endüstriler tarafindan kullanılmakta olan ve meta olarak sunulan hayvan hayatlarının, yaralanabilir, yaşanabilir ve yası tutulabilir birer can olarak temsil edileceği bağlamı da yaratmalıdır. Diğer taraftan hayvan foto muhabirliğinin anlatım dili belgesel fotoğraf geleneği ile de örtüşmekte ve uzun soluklu çalışmalar da bu çatı altında yer almaktadır.

Hayvan foto muhabirliği ile ilgili tanımlama ya da kavramsal çerçeve çizme çabası aslında temel olarak onun işlevselliğine dair soru işaretleri ortaya konularak amacına ulaşabilir. Başta sorduğumuz iki soru ve aradığ1 yanıtların birleştiği nokta burasıdır. Asıl soru ise şudur; foto muhabirliği ya da belgesel fotoğraf bundan 100 küsur yıl öncesinden başlayarak insan hayatına dair yarattığ1 etkiyi, günümüzde hayvanların yaşam koşulları üzerinde sağlayabilir mi? Tarihsel örneklerini göz önüne aldığımızda, foto muhabirliği ya da belgesel fotoğrafin kökenlerinin kamuoyunu bilgilendirmek, yaşanan toplumsal sorunları görünür kilmak ve bir adım ilerisinde ise sorunun çözümüne dair girişimlerde bulunmak gibi toplumsal fayda amaçlı bir yaklaşıma dayandığını biliyoruz. Foto muhabirliği ve belgesel fotoğraf geleneği henüz 19. yüzyıl sonunda insan hayatlarına odaklanmış, insanların çalışma ve yaşam koşulları, maruz kaldıkları zulüm ve yaşamlarını olumsuz etkileyen savaş, göç, açlık ve doğal afetler gibi olgular o tarihlerden bu yana bu anlatının konusu olagelmiştir. Yaşananlara 1şık tutan ve insan hikâyeleri anlatan bu geleneğin oluşumunda yukanda belirttiğimiz gibi gerçekleri aktarma misyonu etkili olmuştur. Bu çerçevede henüz 1800’lü yllların sonu ve 1900'lerin başında göçmenler üzerine yaptığı çalışmalarla Jacob Riis ve çocuk işçilerin çalışma koşullarıyla ilgili çalışmasıyla Lewis Hine bu alanda öncü olmuştur (LacayoveRussel, 1995, s. 55-62). Freund, New York'un aşağı mahallelerinde yaşayan insanların yaşam koşullarının konu edildiği yazıları desteklemek üzere Riis (2006, s. 99)tarafindan gerçekleştirilen çalışma vasıtasıyla fotoğrafın ilk defa toplumsal eleştiri malzemesi olarak kullanıldığını belirtir. 
İlk örneklerinin ortaya çıtı̆̆̆ erken dönemlerden itibaren farklı fotoğraf çalşmaları ve toplumsal olaylarla gerçekleştirilen tanıklıklar dâhilinde fotoğraf, gerçekliği aktarma misyonunun getirisini üstlenerek problemlerin saptanmas1, aktarılması, kendilerini temsil edebilme gücünden yoksun olan gruplara temsil imkanı tanıması ve kamuoyuna gerçeklerin aktarılması gibi önemli toplumsal görevler üstlenmiştir. Bu gelenek içerisinde, hayvan foto muhabirliği de yukarıda bahsettiğimiz çerçevede, günümüzde hayvanların yaşadığı sorunları dile getirme misyonunu üstlenmiş, foto muhabirliğinin bir alt dalı olarak ortaya çıkmış ve biçimlenmiştir. Son yıllarda fotoğrafçıların özellikle ekolojik sorunları dile getirme eğiliminin giderek arttı̆̆1 gözlemlenmektedir. Çalışmalarını bu kapsamda ortaya koyan fotoğrafçılar özellikle nesli tükenen ve doğal yaşam alanları insanlar tarafindan giderek daha fazla işgal altına alınan hayvanlara ilişkin fotoğraflar ortaya koymakta ve hayvanlar giderek daha fazla temsil alanı bulmaktadır. Elbette özellikle ekoloji gibi bütün yaşamların birbirine bağlı olduğu bir alandan hayvanları soyutlamak ya da örneğin küresel 1sınmadan, katledilen Yağmur Ormanlarından ayrı düşünmek mümkün değildir. Ancak bu sınıflandırma hayvanlara ilişkin temsil olanaklarını arttırdığı gibi onların doğru bağlamlarda kamuoyuna sunulmalarına ve bu kapsamda doğru temsil edilebilmelerine olanak sağlayacaktır.

$\mathrm{Bu}$ çerçevede günümüzde hayvan foto muhabirliğinin öncüsü ve bu tabiri ilk kullananlardan biri olarak Jo-Anne McArthur öne çıkmaktadır. Kendisini hayvan foto muhabiri olarak tanıtan McArthur aynı zamanda yazar, hayvan hakları aktivisti, "We Animals Media" ajansının kurucusu ve eğitmendir. McArthur'un, 2003 yllında resmi olarak hayata geçirdiği, We Animals projesi günümüzde bir medya ajansına dönüşmüş ve adeta hayvan foto muhabirliğinin hayat bulduğu bir kurum haline gelmiştir. Giderek büyüyen ve hayvan hakları ihlalleri karşısında daha etkin rol oynayan ajans çatısı altında, hayvan hakları ihlallerine tanıklık eden projeler yürütülmekte, konuya ilişkin haber ve hikâyeler yeni medyanın olanaklarını kullanarak dünya geneline servis etmektedir. We Animals Media aynı zamanda hayvan hakları savunucularına bir çatı oluşturmakta, haber servis etmenin yanında kitap yayınlamakta ve hem medya hem de fotoğraf alanında hayvan foto muhabirliği ile ilgili eğitim içerikleri hazırlamaktadır. Bu anlamda McArthur ve kurmuş olduğu We Animals Media ajansı, görüntü üretim, dağitım ve hayvanları temsil etme misyonunun öncülüğünü yapmak bir yana kurumsal olarak da bu yaklaşımın gelişmesinde ve uluslararası alanda kabulünde önemli bir rol oynamaktadır. We Animals Media gibi bir öncü hareketin de katkısıyla hayvanların temsili ile ilgili çalışmalar gerçekleştiren foto muhabirlerinin sayısının her geçen gün arttı̆̆ ve McArthur'un yanı sıra özellikle Aitor Garmendia, Aaron Gekoski gibi isimlerin bu konuda yaptıkları çalışmalarla öne çıktıklarını belirtmeliyim. Konuyla ilgili kavramsal çerçeve oluşturmayı amaçladığım bu ilk makalede, öncü fotoğrafçıların gerçekleştirmiş oldukları ve hayata geçirilen, hayvan foto muhabirliğine ilişkin çalışmalardan bu kadar bahsetmekle yetineceğim ancak bu konuda üretilen çalışmaların konuyla ilgili bir başka makalemin içeriğini oluşturacağını da eklemeliyim.

Bu çerçevede, hayvan foto muhabirliği üslubu dahilinde üretilen hayvan temsillerinin, bu yaklaşımın dışında hayvanların birer meta olarak pazarlandığı, turizm, güzellik, eğlence ve gıda gibi sektörlerin allayıp pullayarak bizlere sunduğu hayvan imajlarının, hayvan foto muhabirliğinin ürettiği imajlarla uyuşmadığının belirtilmesinde fayda bulunmaktadır. Hayvan foto muhabirliği gezegende yaşayan hayvanların, insan yaşamı tarafından ihlal edilen hayatlarını görünür kılmayı ve onların seslerini duyurmayı amaçlamaktadır. Bu açıdan, laboratuvarlarda, gıda sektöründe ve eğlence sektörlerinde kullanılan hayvanlardan, sokak hayvanlarına kadar hayvan yaşamı ve refahı hayvan foto muhabirliğinin görüş alanına girer. Çevre foto muhabirliği nasıl coğrafi güzellikleri yansıtmayı hedeflemiyor ve çevre sorunlarını, atıkları, bunlarla yaşamak zorunda olan insanları ve ekolojik problemleri konu ediniyorsa, hayvan foto muhabirliği de hayvanları birer tüketim ya da sempati nesnesi olarak değil, insan yaşamından olumsuz etkilenen ve ac1 çeken canlılar olarak temsil etmeyi ve bu konuya ilişkin yeni bir görme biçimi yaratmayı amaçlamaktadır. $\mathrm{Bu}$ yeni görme biçimi onların sorunlarını dile getirerek çözüme kavuşturmak adına fotoğrafın tarihsel olarak üstlendiği gerçekliği aktarma misyonunu, yani foto muhabirliği ve belgesel fotoğraf geleneğinin temelleri üzerine kuruludur.

\section{Sonuç}

Hayvan foto muhabirliği, son yıllarda artan bir hızda kamuoyu gündemine gelen hayvan hakları ve hayvan refahı konusundaki temsiliyet gücü ve etkisi nedeniyle hem medya çalışmalarında hem de fotoğraf alanında değerli bir çalışma alanı haline gelmeye aday gözükmektedir. Günümüzde hem küresel ssınmaya, hem ekolojik dengeye hem de hayvan haklarına ilişkin artan duyarllık ve titreşimli kültürel iklimin, tarihsel süreçte oluşturmuş olduğu gelenek gereği, foto muhabirliği ve belgesel fotoğrafı zorunlu olarak bu alana itmiştir. Bu söylem dahilinde hayvan foto muhabirliğinin giderek daha fazla önem kazanacağ1 ve bu 
vesileyle hayvanların bu kapsamda daha fazla temsiliyet alanı bulacağı düşünülmektedir. Son yıllarda farklı alanlardaki hayvan hakları ihlallerini çalısan fotoğrafçı sayısı giderek artmakta, hayvanlar daha fazla temsiliyet alanları bulabilmekte ve bu durum da konuya karşı duyarlılığı arttırmaktadır. Böylelikle hem hayvanları çalışan foto muhabirlerinin sayısı artmakta hem de sesleri daha gür çıkmaya başlamaktadır. Bu noktada henüz hayvan foto muhabirliğine ilişkin kavramsal çerçevenin yeni oluşturulmaya başlandı̆̆ını göz önünde bulundurursak, önceki yıllarda hayvan refahına ilişkin ortaya konulan çalışmaların öncü çalışmalar olarak ele alınması gerektiğini söylemeliyiz. Konuyla ilgili literatürdeki ilk çalışma olma özelliği gösteren bu makale, öncü bir çalışma olarak kavramsal çerçeve oluşturma, alanın işlevselliğini tartışma ve kısaca da olsa öncü fotoğrafik üretimleri sunma amacındadır. Bundan sonraki çalısmalarımın bir nüvesi konumundaki bu makalenin, hayvan foto muhabirliği ve hayvan hakları ve fotoğraf ilişkisi konusundaki çalışmalar için de aydınlatıcı olmasını ummaktayım.

Fotoğrafa içkin tartışmalar elbette bu kavram etrafında gerçekleştirildiğinde bazı noktalarda hayvan foto muhabirliğinin etkisinin pek de fazla olmayacağı ifade edilebilir, ancak günümüzde dahi etkisi görülen savaş fotoğrafina ilişkin tartışmaların fotoğraf tarihi boyunca gerçekleştiğini ve tarihin bazı dönemeçlerinde fotoğrafa biçilen rollerin savaşları bitirme noktasına kadar geldiğini hatırlatmakta fayda görüyorum. Tarih sahnesinde tanık olduğumuz bazı örneklerde de görüldüğü gibi fotoğrafın etkisinin kitleleri harekete geçirecek kadar vurucu olması ve fotoğrafin gösterdiği olaya ilişkin anlık bir çözümün bulunması elbette ütopik bir durum oluştururdu. Bunun yanında tarihsel süreçte fotoğrafçıların olaylara yaklaşımlarındaki insani boyut vasıtasıyla acıları görme pratiği ortaya çıkmış ve insancıl fotoğrafik bakış yukarıda bahsettiğimiz gibi bir algilama ya da görme biçimi yaratmıştır diyebiliriz. 19. yüzyll sonu ve 20. yüzyllın başlarında ortaya çıkan insancıl fotoğrafik bakış açısının 21. yüzyılın başında hayvanlara yöneldiği ve bu anlamda hayvan foto muhabirliğinin henüz yolun çok başında olduğunu söyleyebiliriz. Buna bağlı olarak insanlarda genel olarak hayvan haklarına dair sorunları görme kapasitelerini artıracak bir etkisinin olacağı düşünülmektedir. Hayvanların gelen olarak birer ürün ya da eğlence nesnesi olarak temsil edildiği medyada, hayvan foto muhabirliğinin öncü olacağı temsil biçimleri bir canlının yaşamına saygı gerektiren temsillerin gerekliliğini görmenin önünü açacaktır.

Mevcut temsil edilme biçimleri içerisinde hayvanlar, gıda endüstrisinin birer ürünü, eğlence sektörünün nesnesi ya da fethedilmesi gereken birer egzotik güzellik olarak sunulmakta ve bu durum onların acı çekme kapasitesine sahip birer canlı olarak idrak edilebilmelerini güçleştirmektedir. Bu sebeple günümüzde henüz, Butler ve Sontag’ın fikirlerinin mevcut fotoğrafik temsiller çerçevesinde gerçekleştirdiği çatışma, hayvan hakları ve hayvan foto muhabirliği açısından ileri tartışmalardır. Temsiliyet problemi yaşayan ve bu anlamda Butler'in deyimiyle yas hiyerarşisinde en sonlarda gelen hayvanların görünür kılınmalarında hayvan foto muhabirliğinin önemli bir rol oynayacağını düşünmekteyim. We Animals Media gibi mecraların ve günümüzde birçok foto muhabiri tarafindan çalışılmaya başlanan hayvan haklarına ilişskin konulara gösterilen ilgideki yükselişle birlikte bu dil gelişecek ve daha etkili hale gelecektir. Hayvanların yaşamış olduğu sıkıntıların, hayvan hakları ihlallerinin görünür hale gelmesi ve bu anlamda doğru temsil biçimlerinin ortaya konulması ile hayvan foto muhabirliğinin, hayvanların çektikleri 1stırabın giderilmesi ve seslerinin duyurulması konusunda oynadığı rol daha net bir şekilde ortaya çıkacaktır. Henüz ilk örneklerini vermekte olan bu yaklaşımın, fotoğraf tarihinde yer edinecek kadar kök salmamıs olmakla birlikte yaşadığımız çağın koşulları içerisinde kendini var edeceğini ve foto muhabirliği üslubu dâhilinde varlığını sürdüreceğini öngörmekteyim.

\section{Etik Beyan}

"Hayvanların Acısına Bakmak: Hayvan Foto Muhabirliğine Dair Kavramsal Bir Çerçeve" başlıklı çalışmanın yazım sürecinde bilimsel, etik ve alıntı kurallarına uyulmuş; toplanan veriler üzerinde herhangi bir tahrifat yapılmamış ve bu çalışma herhangi başka bir akademik yayın ortamına değerlendirme için gönderilmemiştir. Bu araştırmada doküman incelemesi yapıldığından etik kurul kararı zorunluluğu bulunmamaktadir.

\section{Kaynakça}

Berger, J. (2017). Hayvanlara niçin bakarı?? (Çev: C. Çapan). İzmir: Tudem Yayın Grubu.

Butler, J.C. (2018). Kırlgan hayat (Çev: B. Ertür). İstanbul: Metis Yayınları.

Butler, J. (2015). Savas tertipleri (Çev: Ş. Öztürk). İstanbul: Yap1 Kredi.

Freund, G. (2006). Fotoğraf ve toplum (Çev: Ş. Demirkol). İstanbul: Sel Yayıncilık.

Güçlü, Ö. (2018). Hayvanın felaketi, manzaradan lekelere, hayırsızada (Serge Avedikian, 2010). Kebikees, 46, 351-365. 
Lacayo, R. ve Russell, G. (1995). Eyewitness, 150 years of photojournalism. New York: Time Home Entertainment Incorporated.

Singer, P. (2005). Hayvan özgürleşmesi (Çev: H. Doğan). İstanbul: Ayrıntı Yayınları.

Singer, Peter (2012). Pratik etik (Çev: N. Çatlı). İstanbul: İthaki Yayınları.

Sontag, S. (2004). Başkalarmm acısına bakmak (Çev: O. Akınhay). İstanbul: Agora Kitaplığı.

Sontag, S. (1999). Fotoğraf üz̧erine (Çev: R. Akçakaya). İstanbul: Altıkırkbeş Yayın.

\section{EXTENDED ABSTRACT}

The discussion of whether the expressive and/or representation of the destructive relationship with animals trapped in the world occupied by humans will be beneficial in terms of establishing animal welfare or improving the living conditions of animals constitutes the topic of this article. Can animal photojournalism, which has made it their duty to make animal lives visible and to show and end their suffering, succeed in this? We will have the chance to see the answer to this question more clearly with the practices that will be introduced in the coming years. In this context, we will limit our article to determining the conceptual framework for animal photojournalism that has taken on this responsibility. In the article, the animal-human relationship is revealed within the approach of Peter Singer. The article was grounded on the utilitarian approach of Peter Singer, who deals with this relationship within the framework of practical ethics and is one of the pioneers in this subject with the book "Animal Liberation". Under the principle of equality, the interests of every living thing should be equally important. The primary motive of animal photojournalism, which undertakes the photographic representation of the pain of the animals suffering in the human world, is to ensure that the suffering is given equal importance. At this point, the representation of the animals' pain through photography and the impact it will have on the masses are evaluated within the framework of the views of Judith Butler and Susan Sontag. First of all, speciesism was deployed alongside racism and sexism that were against the principle of equality. Butler was primarily addressed because of her views on animal life being grievable or precarious. Because, according to Butler, the criteria determined around specific frameworks require the acceptance of life as life first. Afterward, the views of Sontag regarding the functions of the photographs in reflecting human suffering have been included within the framework of the opinions she has put forward in her book titled "Regarding the Pain of Others," which inspired the name of this article. Finally, in this context, "Animal Photojournalism" or "Animal Rights Photography" and the functionality of this genre were discussed.

As a result of the human existence spreading over the planet, the habitats of wild animals are rapidly invaded, on the other hand, with industrial production, animals are raised under inappropriate conditions, they are forced to leave their mothers or offspring as soon as they are born and sent to death after their short but painful lifetimes. In recent years, different visual expression methods, especially photography, have been used to document these processes and deliver them to the public, and to increase the sensitivity of this subject and to be the voices of animals. This approach, called "Animal Photojournalism," aims to witness the lives of animals that have been tortured on different grounds in people's world and to present their suffering to the public.

Animal Photojournalism, as its name suggests, takes its subject from the living conditions of nonhuman animals under the narrative of photojournalism. Animal photojournalism is a language of expression in which animal rights violations are expressed in a photojournalistic style, and aimed at the visual representation of animals not represented in public. While the animal photojournalist makes this narrative, it should also create the context in which animal lives, which have been converted into show objects or used by different industries and presented as meta, will be represented as vulnerable, livable, and grievable lives. On the other hand, the narrative language of animal photojournalism matches up with the tradition of documentary photography, and the long-term projects are also under this roof. Today, I foresee that the increased sensitivity and vibrating cultural climate-related to global warming, ecological balance, and animal rights will necessarily push photojournalism and documentary photography to this field, due to the tradition it has created in the historical process. In recent years, the number of photographers working on animal rights violations in different areas has been increasing, animals can find more representation areas, and this increases the sensitivity to the subject.

To the best of our knowledge, this article will be the first study regarding animal photojournalism in the academic field. It aims to create a conceptual framework as a pioneering study, discuss the functionality of the area, and briefly point out the leading photographers. In the current forms of representation, animals are presented as products of the food industry, the object of the entertainment 
industry, or an exotic beauty that needs to be conquered. This situation makes it difficult to perceive them as creatures capable of suffering. For this reason, the conflict that Butler and Sontag's ideas have carried out within the framework of the existing photographic representations is an advanced discussion in terms of animal rights and animal photojournalism. In this respect, I think that animal photojournalism will play an essential role in making animals visible. This genre will develop and become more productive with the increasing number of media such as We Animals and photojournalists working on animal rights violations long-term projects. As the last word, we can say that the humanitarian photographic perspective that emerged in the late 19th and early 20th centuries turned towards animals at the beginning of the 21st century. In this sense, animal photojournalism is at the very beginning of the road. 